\title{
ワシントン アコード
}

おおはし ひでお

工学院大学学長

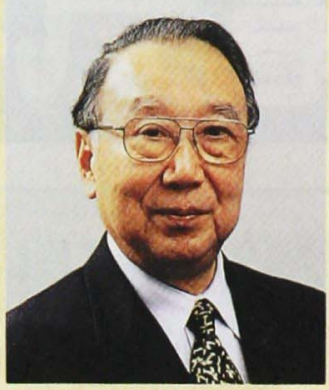

ワシントン条約（野生動植物の取引規制）に比べてワシ ントン協定 (Washington Accord, 以下 WA) を知る人は 少ない。WA は 1989 年に六ヶ国を代表する技術者教育認 定団体がワシントンに集まつて調印・成立させた協定で, 加盟団体が認定した技術者教育は質的に同等であることを 相互に認め合う仕組みができあがった。最初の加盟国は 米・英・加・豪・NZ・アイルランドであったが，その後 香港と南アフリカが加わり八ヶ国に増えた。何れも典型的 な Anglo-American 諸国である。

これらの国では伝統的に Professionalism が確立してい る。技術者は大学レベルの科学知識をベースにして技術業 に携わるプロとして認知され，CEng などの技術者資格 は，技術を志すものにとって当然の目標となる。このよう な国での技術者教育の認定は，学位の質保証というより技 術者資格の一次関門としての役割が強い。

加盟国中，米国だけはこの点異端である。大学の設置が 自由で私学の比重が高く，大学が次々に設立される米国で は, 評価に困った産業界が悲鳴をあげた。これに対する大 学側の対応が認定制度の導入であり，工学系では 1930 年 代から ABET が認定団体としての役割を果たしてきた。 このような経緯から, ABETの認定と州が認可する技術 者資格 PEとの間には直接的な関連はない。

我が国の状況は米国に極めて近い。日本を代表する認定 団体として日本技術者教育認定機構 JABEEの設立を構想 したとき，ABETを基本的なモデルとしながらも，認定 と技術者資格（技術士）との関連を強化するなど独自な基 本戦略を採ることにした。昨年 4 月から施行された改正技 術士法では，このことが認定プログラム修了者に対する技 術士一次試験免除の形で具体化された。

JABEE は 99 年の設立当初より, 技術者教育の質保証 と国際同等性の担保を主要な目的としている。したがって WA 加盟は, 設立以来の宿願である。加盟には二段階があ る。先ず総会で暫定加盟が承認されたのち，審查・認定の 過程を加盟団体に公開して同等性の確認を受ける。そして 次回以降の総会で正式加盟を申請し，全加盟団体の賛成を 条件に仲間入りを果たすことができる。
WA の第 5 回総会は昨年 6 月南アフリカで開催された。 そこで設立 1 年余の JABEE が暫定加盟の申請に踏み切る かどうかは，大きな賭であった。時期尚早という奬念を押 し切ったのは, 結局は新生 JABEEにみなぎる活力であっ た。総会は，大都会を避けてクルーガー国立公園に隣接す るサファリで行われた。ライオンやヒョウなどの野獣が繰 ク広げる弱肉強食の世界の中に電気フェンスで守られたロ ッジがあり, 観光客に安全で快適なサファリーライフを提 供している。不審者の侵入もなければ会議のエスケープも 許さない，会議場としてはまことに理想的な条件を備えて いる。

JABEE を代表して副会長の私と, 基準・試行委員長大 中逸雄大阪大学教授, 原田耕作専務理事が参加した。会議 二日目, JABEEに 30 分の説明時間が与えられ，私が組 織と執行体制，大中教授が基準と審査体制について説明し た。質疑が終わると会場から退出を求められ，加盟団体に よる審議が続けられた。結果は朗報であった。議長から 「全加盟団体の賛成を得て暫定加盟が決まった」と告げら れたときの喜びは，生涯忘れられない。

スイスの経営開発国際研究所 IMD が発表する 2001 年 競争力ランキングによると, 我が国の総合ランキングは 26 位, 大学教育部門はどん尻の 49 位である。このような 哀れな状況の中で加盟国全員の賛成が得られたことは奇跡 に近い。その理由を考えてみると, 先ず学協会, 官, 産が 一致して JABEEを支援していることを明確に示せたこ と, 日本産業の底力に対する畏敬の念が強く残っていたこ とを挙げることができる。日本が本気になればきっとやる だろうという期待感は，幸いまだまだ強い。

JABEE は 2001 年度に 51 プログラムの認定試行と, ご く少数の本番の認定を完了する。2002 年度には試行主体 から本番主体の認定に移行し，それを加盟国に公開する新 しい段階に入る。2003 年香港で開催される次回 WA 総会 が，最短で正式加盟を実現するチャンスである。番査・認 定の主役である電気学会を始めとする学協会のご支援と, 大学関係者のご理解を得て, 非英語国として初の加盟実現 を果たしたいと願っている。 